\section{ECONOMICS}

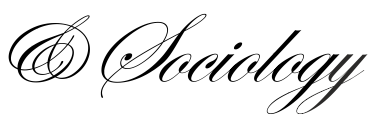

Tovmasyan, G. (2021). Capital investments, tourist tax and tourism development: The case study of Armenia. Economics and Sociology, 14(1), 199-213.

doi:10.14254/2071-789X.2021/14-1/13

\title{
CAPITAL INVESTMENTS, TOURIST TAX AND TOURISM DEVELOPMENT: THE CASE STUDY OF ARMENIA
}

Gayane Tovmasyan AMBERD Research Center, Armenian State University of Economics,

Management Chair, Public Administration Academy, Yerevan, Republic of Armenia E-mail: tovmasyangayane@yaboo.com ORCID 0000-0002-4131-6322

Received: March, 2020

1st Revision: January, 2021

Accepted: March, 2021

DOI: $10.14254 / 2071-$ 789X.2021/14-1/13

JEL Classification: Z3, L83, $\mathrm{H} 2$

\begin{abstract}
Tourism receives money from people and places, but it gives back very little. In this case many countries apply tourist tax, which tourists pay while staying at hotels. The collected money is used for financing tourism development projects. The correlation is made between some factors of tourism, which shows that many factors contribute to tourism development. The regression model was created which shows that tourism contribution to GDP will be changed depending on capital investments in tourism, government spending on tourism, international arrivals and receipts from international arrivals. The article proposes applying tourist tax in Armenia, and money from it is offered to be spent on different programs for tourism development: tourism marketing, branding, investments in tourism infrastructures, etc. The survey done in the article shows that tourists mainly agree with the application of this tax and they indicate the necessity of using the gathered money more effectively. The cross tabulation and Pearson Chi Square analysis show that tourists who think that applying tourist tax in Armenian hotels is a good step for raising money for this sector development, will continue to stay at hotels if the tourist tax at the rates of $1-3 \%$ is applied.
\end{abstract}

Keywords: tourism, tourist tax, tax rate, hotel facilities, investment, cross-tabulation, survey, regression, correlation, Armenia.

\section{Introduction}

Tourism development depends on different factors, one of which is investments. One source of investments may be tourist tax which is already applied in many countries.

Nowadays, many countries are using tourist tax to direct the money gathered from this tax towards the development of tourism infrastructure and investments in tourism.

At the same time, the experience of different countries in this field has shown that tourists, paying the tourist tax, realize their contribution to the development of tourism in a country and feel responsible for the promotion of tourism and the related services. 
In Armenia tourism has been growing recently. However, there are many problems and obstacles for its development, one of which is lack of money. For this very reason, the article offers to apply tourist tax, $1-3 \%$ on the top of the hotel price, while money from this tax should be spent on different programs for tourism development. The article suggests setting certain amount of money as a minimum, which will be directed towards tourism development in the regions and the rest should be used for financing various projects which the Tourism Committee of the Republic of Armenia sets as the priorities based on the annual tourism development plan.

The structure of the paper is as follows: first, the main literature sources about tourist tax are analyzed. Then the methodological part describes how this research is done. Data analysis shows the main findings and the results, based on which the conclusions are then formulated.

\section{Literature review}

Tourism generates profit from places, people and the environment, but returns insignificant part. Tourism also provides employment and infrastructure development. In this case tourism planning should consider the negatives and positives of higher visitor numbers, and understand that more tourists do not always mean "better". So, more and more destinations around the world are applying tourism taxes, to increase funds that can help lessen the negative effects of tourism (Responsible travel, n.d.).

Many countries of the world have a tourist tax, the money of which goes to protecting natural resources and maintaining tourism facilities (Christine, 2019).

Money from tourist tax is used for financing and maintaining facilities of the touristic destination, as well as producing brochures, modernizing tourist attractions including museums and castles (Interrailing packages, n.d.).

According to some researchers (Schubert, 2010; Sheng et al, 2017) financial resources are needed for keeping and improving the existing facilities, also constructing new ones.

Besides, tourism can lead to a degradation of the natural (Schubert, 2010; Sheng et al, 2017) environment. According to Rinaldi (2014) tourism may damage built environment, also tourists produce congestion, pollution.

According to Sheng \& Tsui (2009), La Scala (2013) and Quarto (2013), tourism tax can repair the market failures caused by tourism and increase the government tax revenues which may be used to promote tourism activities and attractiveness.

However, according to Rinaldi $(2011,2012)$ in order to produce the desired positive impacts, the tax should be based on: equity; efficiency, stability, simplicity and cost effectiveness.

La Scala (2013) and Tavares (2011) mentioned that for increasing the tourists' willingness to pay for the tax, it is necessary to explicitly declare how the tax proceeds will be used and to increase tourists' awareness about the rationale of the tax.

A recent study by Rotaris and Carrozzo (2019) aimed at assessing the acceptability of a tourist tax and at studying how it should be designed in order to meet the tourists' preferences better while improving the tourism sustainability. A survey was conducted in two Apulian touristic towns: Otranto and Castro. The results demonstrate that the willingness to pay for the tourism tax depends not only on the vacation and the tourist type, but also on how the fiscal revenues are used. If no mention is made about the use of the tax revenues the willingness to pay can be as low as $€ 0.85$ per person per night, which is much lower than the tax actually levied. Instead, if the tax revenues are used to improve and protect the environment, the willingness to pay can be as high as $€ 3.96$. 
A study in Hawaii tourism sphere showed that it is better to have hotel tax, which room occupants will pay to fund tourism public services than to increase hotel property tax (Mak, 2015).

A recent study in US eight destinations examined the effect of lodging tax increase, finding out that when a city's hotel tax greatly increases above that of an easily accessible competitor, it will not result in an economic loss to the city with the disproportionate tax rates (Hudson et al., 2019).

Another recent study applies tax planning theory to develop a seasonal tax strategy as an alternative to a fixed tax rate for shared lodging platforms such as Airbnb, to increase hosts' revenue and to address seasonality in tourism (Dalir, 2020).

Since January 1, 2020 Amsterdam is implementing an additional charge on top of the existing $7 \%$ tourist tax. The charge also applies to hotels, apartments, campsites and rented private accommodations such as Airbnb. Hotels will charge 3 euros per night, per person, while those who want to stay in camping sites have to pay an extra 1 euro per person, per night. Additionally, the tax rate for rented private accommodations has increased by $10 \%$. The regulation is also applied to sea and river cruise operators and they will be charged 8 euro for each passenger who only stops over and is not a resident of the city. By applying this tax they want the tourists to contribute more to the high costs of keeping the city safe and clean, and of keeping the public place like pavements, quays, bridges and streets in a good state (The Jakarta post, 2020).

The size of tourist tax varies from country to country and depends on the qualification grade of the hotel facilities and the stars. For example, in Ukraine it should not exceed 23.62 hryvnia for domestic tourists and 236.15 hryvnia for foreign tourists (Finance Liga, 2020), in Vienna it ranges from 0.36 euros to $3.2 \%$ of room price per night, in Paris - 0.23-4.60 euros, in Berlin is 5\% of the room price, in Greece - 0.5-4 euros, in Budapest is $4 \%$ of the room price, in Rome is 3-7 euros, and 0.45-2.25 euros in Barcelona, etc. (Monitoring and travel, 2020).

\section{Methodological approach}

The aim of the study is to observe a new mean of financing tourism development programs in whole country. In this terms, the application of tourist tax is offered.

In the article some methods are used: abstraction, sociological survey, statistical and graphical methods.

The method of abstraction is used by disregarding unimportant features, relationships of the objects being studied, and at the same time identifying or highlighting one or more aspects which are more important. In this case the all other problems of tourism development in Armenia were disregarded and the concentration was made only on financial issues.

Correlation and regression methods were used to evaluate connections between investments, tourism contribution to GDP and other factors.

The qualitative and quantitative assessment is done via survey among 100 people, the results of which are analyzed in the paper. Some results are analyzed via Crosstabulations with Pearson Chi-square coefficient testing (setting significance level $\alpha=0.05$ ). The value of the Chi Square statistic provides a test whether or not there is a statistical relationship between the variables in the cross-classification table.

The graphical method is used for graphical interpretation of the research results.

For accomplishing the survey, the following hypothesis is derived:

1. Relationship between the opinion of respondents about the application of the tourist tax by the hotels and willingness of people to stay at hotels.

H1: In case of applying the tourist tax people will continue to stay at hotels. 

more.

H0: In case of applying the tourist tax people will not continue to stay at hotels any

The novelty of the article is the following: tourist tax is offered to apply, some calculations are done and the main directions of usage of the allocated money are suggested.

\section{Conducting research and results}

\subsection{Tourism in Armenia}

According to the official statistics, tourism is considered to be one of the fastly developing sectors of the Armenian economy, showing growth trends year by year. According to the RA Statistical Committee data, in 2019 the number of incoming tourists in Armenia was 1894377. Compared to last year, the number of arrivals increased by $14.7 \%$ (Socio-economic situation of the RA in 2019 January-December, 2020). Because of Covid-19, tourism sector had negative impacts also on Armenia. As seen from Graph 1, the number of incoming tourists decreased up to $80 \%$ in 2020 (Socio-economic situation of the RA in 2020 January-December, 2021).

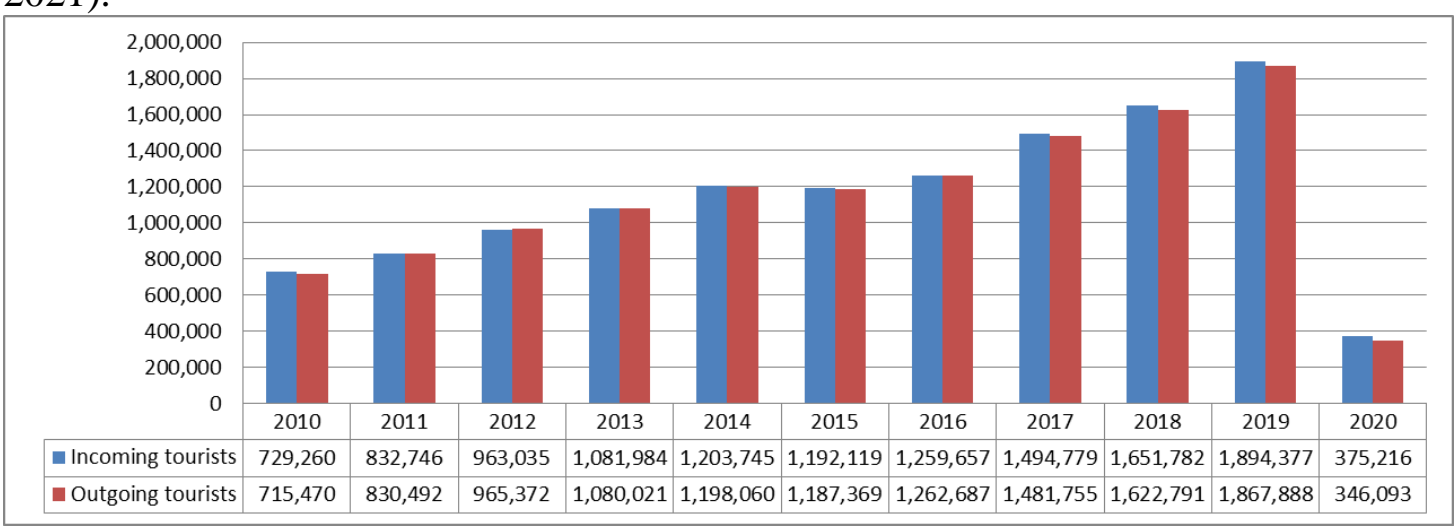

Graph 1. Number of incoming and outgoing tourists in Armenia, 2010-2020

Source: Socio-economic situation of the RA for 2010-2020 years

According to World Travel and Tourism Council publications the total impact of tourism on GDP in Armenia was 1,6 bn USD or 11.8\% of GDP in 2019. The total impact of tourism on employment made up 124,600 jobs, or $12.5 \%$ of total employment (WTTC Travel \& Tourism Economic Impact Armenia, 2020).

According to the World Bank data, based on the analysis of the World Travel and Tourism Council, the capital investments in tourism sector in Armenia in 2018 were 0.12 billion USD.

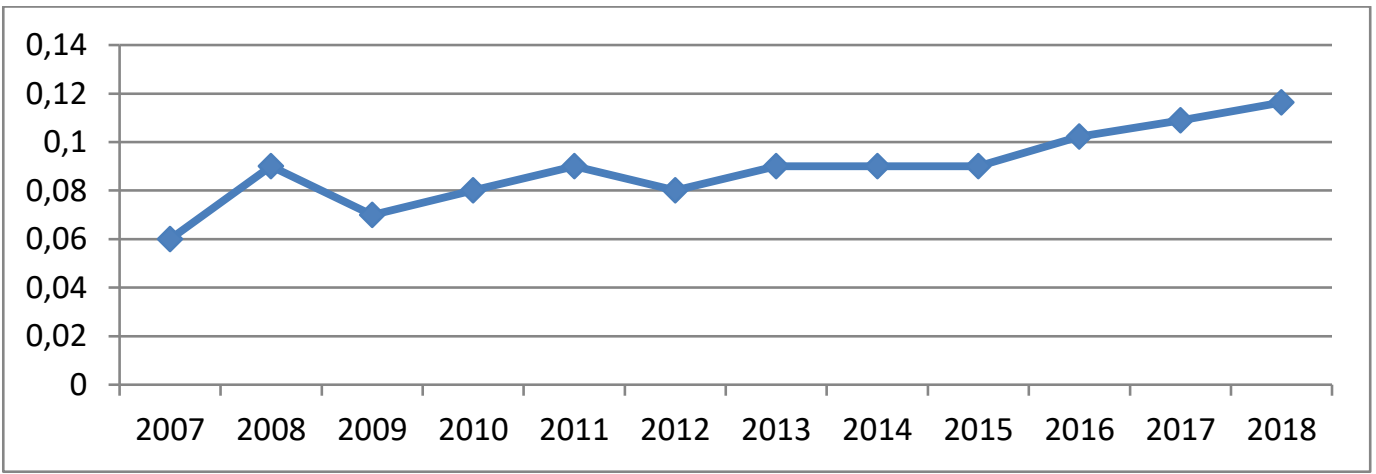

Graph 2. Capital investment in tourism, US\$ in bn (Nominal prices), 2007-2018 Source: Compiled by the author based on World Bank data on Capital investment in Travel and Tourism 


\subsection{Application of correlation and regression analyses}

In order to evaluate the correlation between capital investments, number of tourists, GDP and other variables in tourism, correlation and regression analyses were done.

Table 1. Correlations between some factors

\begin{tabular}{|c|c|c|c|c|c|}
\hline & $\begin{array}{l}\text { Capital investment } \\
\text { In TT, US\$ in bn } \\
\text { (Nominal prices) }\end{array}$ & $\begin{array}{l}\text { Government } \\
\text { spending, US\$ in } \\
\text { bn (Nominal } \\
\text { prices) }\end{array}$ & $\begin{array}{l}\text { TT total to GDP, } \\
\text { US\$ in bn (Nominal } \\
\text { prices) }\end{array}$ & $\begin{array}{l}\text { TT total to } \\
\text { employment } \\
\text { (Thousands of } \\
\text { jobs) }\end{array}$ & $\begin{array}{l}\text { International } \\
\text { tourism } \\
\text { arrivals }\end{array}$ \\
\hline $\begin{array}{l}\text { Capital } \\
\text { investment In } \\
\text { TT, US\$ in bn } \\
\text { (Nominal prices) }\end{array}$ & 1.00 & & & & \\
\hline $\begin{array}{l}\text { Government } \\
\text { spending, US\$ in } \\
\text { bn (Nominal } \\
\text { prices) }\end{array}$ & 0.90 & 1.00 & & & \\
\hline $\begin{array}{l}\text { TT total to GDP, } \\
\text { US\$ in bn } \\
\text { (Nominal prices) }\end{array}$ & 0.90 & 0.89 & 1.00 & & \\
\hline $\begin{array}{l}\text { TT total to } \\
\text { employment } \\
\text { (Thousands of } \\
\text { jobs) }\end{array}$ & 0.92 & 0.83 & 0.97 & 1.00 & \\
\hline $\begin{array}{l}\text { International } \\
\text { tourism arrivals }\end{array}$ & 0.94 & 0.86 & 0.99 & 0.98 & 1.00 \\
\hline
\end{tabular}

Source: The analysis was done by the author using the data of World Bank, via Excel and SPSS

So, it is obvious that the variables are highly correlated with each other.

Besides a regression model was created evaluating how the total contribution of tourism to GDP will be changed depending from government spending in the sphere, domestic spending on tourism and receipts from international tourism in summary (total expenses).

Table 2. Predicted change of total contribution of tourism to GDP

\begin{tabular}{lcccc}
\hline & Coefficients & Standard Error & $t$ Stat & $P$-value \\
\hline Intercept & $(0.01)$ & 0.01 & $(0.88)$ & 0.39 \\
\hline Total expenses & 1.26 & 0.01 & 158.70 & 0.00 \\
\hline
\end{tabular}

Source: Based on the analysis using Excel and SPSS

The adjusted $\mathrm{R}$ square is 0.99 , the data are for 24 years.

Based on the results, the model will be as follows:

\section{Predicted TT total contr. to GDP, US\$ in bn (Nominal prices) $=-0.01+1.26 x$ Total expenses}

As mentioned above, total expenses here include government spending in the sphere, domestic spending on tourism and receipts from international tourism. The model means that 1 bn $\$$ change in expenses will change the tourism contribution to GDP by 1.26 bn $\$$, or $1 \%$ change in total expenses will lead to $1 \%$ change in tourism contribution to GDP.

In the total expenses, the $83 \%$ change is connected with international tourism receipts, $16 \%$ change is connected with domestic tourism spending and only about $1 \%$ with government spending.

Besides a regression model was created evaluating how the total contribution of tourism to GDP will be changed depending from capital investments. 
Table 3. Predicted change of total contribution of tourism to GDP depending on capital investments

\begin{tabular}{lcccc}
\hline & Coefficients & Standard Error & $t$ Stat & $P$-value \\
\hline Intercept & 0.004 & 0.10 & 0.05 & 0.96 \\
\hline Capital Investment & 14.68 & 1.24 & 11.87 & 0.00 \\
\hline
\end{tabular}

Source: Based on the analysis using Excel and SPSS

\section{Predicted TT total contr. to GDP, US\$ in bn (Nominal prices) $=0.004+14.68 x$ Capital Investment}

So, $1 \%$ change in capital investments of the sphere will lead to $1 \%$ change in TT total contribution to GDP, or 1 bn additional $\$$ in capital investments will change the tourism contribution to GDP by 14.68 bn $\$$.

The Graph 3 shows the scatter chart between capital investments in tourism and the total contribution of tourism to GDP in Armenia.

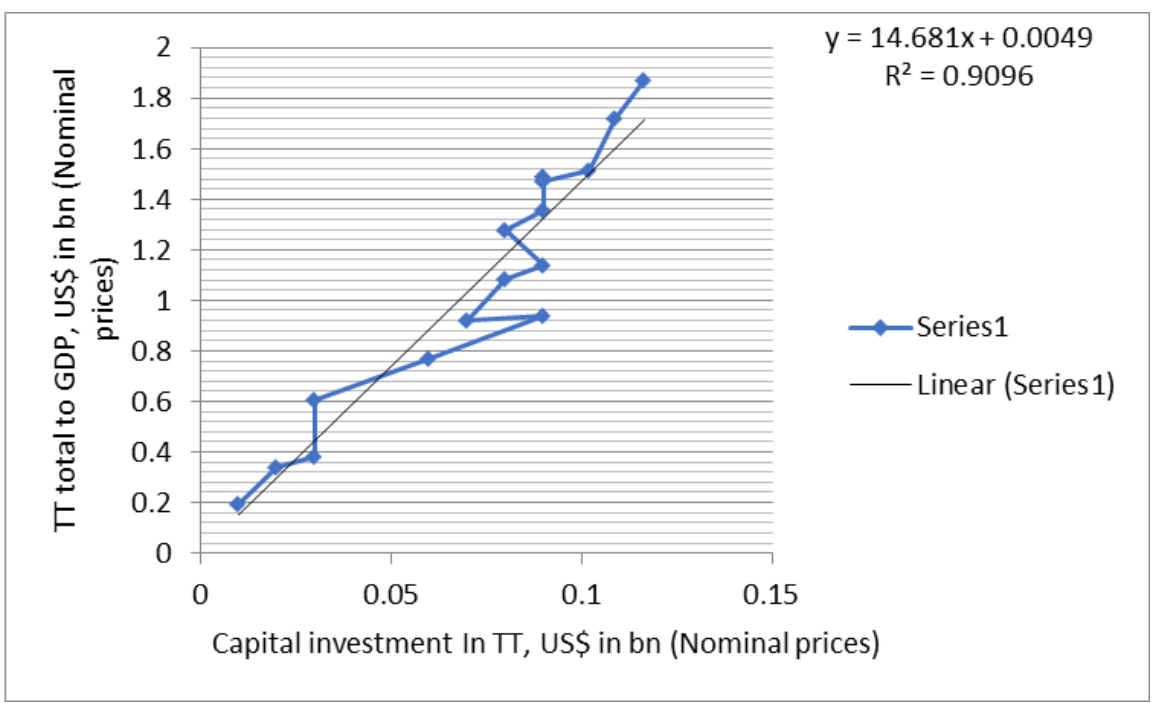

Graph 3. Scatter chart between capital investments in tourism and the total contribution of tourism to GDP

Source: Based on the analysis using Excel

\subsection{Applying tourist tax in Armenia}

In fact, in a number of countries around the world, the tourist tax is used as a source of investments for financing the activities needed to develop the sector.

Tourist tax should also be applied in the Republic of Armenia, which will be paid for overnight stay in hotel facilities.

This article proposes to apply tourist tax in the Republic of Armenia, depending on the qualification of the hotel facilities, as well as on the types of rooms (standard, semi-lux, luxury), and set a $1-3 \%$ on a daily rate. Thus, since the daily cost of a rest in the hotel facilities in Armenia varies between 4000-450000 AMD $^{1}$ (except the cost of presidential rooms, which varies between 500000-1500000 AMD) (Armhotels, n.d.), this research suggests setting 1\% per day for rooms at price 4000-100000 AMD, 2\% for rooms at price 100001-200000 AMD and

\footnotetext{
${ }^{1}$ According to Central Bank of Armenia the exchange rate between USD and AMD is as follows: 1 USD $=526.38$ AMD, as of March 12, 2021.
} 
$3 \%$ for rooms at price higher than 200001 AMD. The tax is to be paid for maximum amount of 7 nights per guest. Guests under age 12 do not have to pay the tax.

According to the Statistical Committee of the Republic of Armenia, there were 709 hotel facilities in 2020, 390 of which were in Yerevan and the remaining 319 were in the regions. The total revenues of hotel facilities amounted to 13786.0 million AMD, $61 \%$ of which was from hotels in Yerevan. Compared to the previous year, the revenue of the hotel facilities decreased by $67 \%$ and the number of hotel facilities decreased by $7.8 \%$. This was because of Covid-19, as the restrictions of international travel influenced the sphere development (Table 4).

After Yerevan, the number of hotel facilities was high in Kotayq (78), Tavush (72) and Syunik (37). The leader in terms of hotel facilities revenue is certainly Yerevan, followed by Kotayk and Tavush.

Table 4. Some data of hotel facilities by regions and by city of Yerevan

\begin{tabular}{|c|c|c|c|c|c|c|c|}
\hline & \multicolumn{3}{|c|}{ Number of hotel facilities } & \multicolumn{3}{|c|}{ Revenue, million AMD } & \multirow{2}{*}{$\begin{array}{c}\text { Number of } \\
\text { incoming tourists } \\
\text { who stayed at hotel } \\
\text { facilities, person } \\
2018\end{array}$} \\
\hline & 2018 & 2019 & 2020 & 2018 & 2019 & 2020 & \\
\hline $\begin{array}{l}\text { The Republic of } \\
\text { Armenia }\end{array}$ & 652 & 769 & 709 & 34497.5 & 41794.1 & 13786.0 & 307473 \\
\hline Yerevan & 390 & 410 & 390 & 27879.9 & 33772.2 & 8476.7 & 265908 \\
\hline Aragatsotn & 5 & 7 & 6 & 106.2 & 87.7 & 54.3 & 93 \\
\hline Ararat & 9 & 8 & 6 & 72.1 & 80.4 & 64.3 & - \\
\hline Armavir & 4 & 15 & 11 & 43.1 & 41.7 & 27.3 & - \\
\hline Gegharquniq & 11 & 39 & 31 & 274.2 & 735.9 & 285.3 & 975 \\
\hline Lori & 19 & 30 & 26 & 323.7 & 354.6 & 264.2 & 394 \\
\hline Kotayq & 65 & 91 & 78 & 2977.4 & 3220.0 & 2342.5 & 7389 \\
\hline Shirak & 28 & 33 & 32 & 400.5 & 576.9 & 271.7 & 6006 \\
\hline Syunik & 37 & 38 & 37 & 629.4 & 830.5 & 339.2 & 1064 \\
\hline Vayots Dzor & 19 & 24 & 20 & 700.5 & 588.0 & 557.4 & 10276 \\
\hline Tavush & 65 & 74 & 72 & 1090.5 & 1506.2 & 1103.1 & 15368 \\
\hline
\end{tabular}

Source: The regions of the Republic of Armenia and the city of Yerevan in numbers, 2019, also data provided from the Statistical Committee of the Republic of Armenia

According to the data of the Statistical Committee of the Republic of Armenia the number of incoming tourists who stayed in hotel facilities was 307473 people in 2018, and in 2017 - 264702 people (Socio-economic situation of the RA in January, 2019). The leaders in this regard are again the hotel facilities in Yerevan. The number of incoming tourists was 265908 in Yerevan, in Tavush - 15368, in Vayots Dzor - 10276, and in Kotayk - 7389. The newer information for this for 2019 and 2020 years is not available yet.

Number of domestic tourists who stayed in hotel facilities in 2018 was 1092322, and in 2017 - 1086707 people (Socio-economic situation of the RA in January, 2019). It should be noted, however, that there is no statistical information on the distribution of the number of domestic tourists in the regions.

So, it may be resumed that in 2017,1351409 tourists (the summary of domestic and incoming tourists) stayed in the hotel facilities of the Republic of Armenia, and in 2018 1399795 tourists. By dividing the revenue of hotels to this number, the average amount paid by each tourist will be 24645 AMD in 2018, 21035 AMD in 2017.

By calculating the tourist tax at the rate of $1-3 \%$ of the revenue of hotels, according to the data of 2018, it will make 344.975.000-1.034.925.000 AMD, and in 2017 - 284.271.000852.813.000 AMD. According to the data of 2019, the tourist tax will be 417,941,000- 
1,253,823,000 AMD (table 5). The calculations were not done for 2020, as the data are preliminary; also it was not a normal year for tourism because of COVID-19.

Since there is no statistics on how many nights tourists spend in hotels and in what type of rooms they sleep depending on prices, the amount of tourist tax may not be calculated more accurately.

Thus, with the usage of this type of tax, it will be possible to accumulate money to invest in tourism development in the country, to finance various events, and so on.

The money gathered from the proposed new tax should be fully spent on financing the projects of tourism. The state should regulate the use of this tax in accordance with the relevant law, setting the procedure, principles, terms and conditions of payment. Targeted use of the tourist tax will contribute to the implementation of investment programs in the tourism, the improvement of infrastructures and the solution of a number of problems in the sector.

It should be noted that in 2009 the Communities Finance Officers Association of the Republic of Armenia processed the draft law of the RA on Hotel Tax, according to which it was to be a local tax, with the aim of increasing the financial capacity of the community and contributing to the development of tourism in the communities.

According to the draft law, the taxable objects and rates should be:

1. hotel facilities for which the state tax liabilities are defined in general terms (value added tax and profit tax), and the rate of hotel tax should be $2-10 \%$ of the actual revenue generated by the hotel service;

2. hotel facilities for which state tax liabilities are defined as a fixed payment, the rate should be for each quarter of the hotel facility area per quarter - 150 - 600 AMD (The draft of the law on "Hotel tax" of the RA, 2009).

Table 5. Possible amount of tax collected as a result of tourist tax

\begin{tabular}{|c|c|c|c|c|c|c|c|c|}
\hline & Revenue, AMD & $\begin{array}{l}\text { Possible } \\
\text { amount of } \\
\text { tourist tax, } \\
\text { AMD (at } 1 \% \\
\text { rate of the } \\
\text { tax) }\end{array}$ & $\begin{array}{c}\text { Possible } \\
\text { amount of } \\
\text { tourist tax, } \\
\text { AMD (at } 2 \% \\
\text { rate of the } \\
\text { tax) }\end{array}$ & $\begin{array}{c}\text { Possible } \\
\text { amount of } \\
\text { tourist tax, } \\
\text { AMD (at } 3 \% \\
\text { rate of the tax) }\end{array}$ & Revenue, AMD & $\begin{array}{c}\text { Possible } \\
\text { amount of } \\
\text { tourist tax, } \\
\text { AMD (at } 1 \% \\
\text { rate of the tax) }\end{array}$ & $\begin{array}{c}\text { Possible } \\
\text { amount of } \\
\text { tourist tax, } \\
\text { AMD (at } 2 \% \\
\text { rate of the tax) }\end{array}$ & $\begin{array}{l}\text { Possible amount } \\
\text { of tourist tax, } \\
\text { AMD (at 3\% } \\
\text { rate of the tax) }\end{array}$ \\
\hline & 2018 & 2018 & 2018 & 2018 & 2019 & 2019 & 2019 & 2019 \\
\hline $\begin{array}{l}\text { The Republic } \\
\text { of Armenia }\end{array}$ & $34,497,500,000$ & $344,975,000$ & $689,950,000$ & $1,034,925,000$ & $41,794,100,000$ & $417,941,000$ & $835,882,000$ & $1,253,823,000$ \\
\hline Yerevan & $27,879,900,000$ & $278,799,000$ & $557,598,000$ & $836,397,000$ & $33,772,200,000$ & $337,722,000$ & $675,444,000$ & $1,013,166,000$ \\
\hline Aragatsotn & $106,200,000$ & $1,062,000$ & $2,124,000$ & $3,186,000$ & $87,700,000$ & 877,000 & $1,754,000$ & $2,631,000$ \\
\hline Ararat & $72,100,000$ & 721,000 & $1,442,000$ & $2,163,000$ & $80,400,000$ & 804,000 & $1,608,000$ & $2,412,000$ \\
\hline Armavir & $43,100,000$ & 431,000 & 862,000 & $1,293,000$ & $41,700,000$ & 417,000 & 834,000 & $1,251,000$ \\
\hline Gegharquniq & $274,200,000$ & $2,742,000$ & $5,484,000$ & $8,226,000$ & $735,900,000$ & $7,359,000$ & $14,718,000$ & $22,077,000$ \\
\hline Lori & $323,700,000$ & $3,237,000$ & $6,474,000$ & $9,711,000$ & $354,600,000$ & $3,546,000$ & $7,092,000$ & $10,638,000$ \\
\hline Kotayq & $2,977,400,000$ & $29,774,000$ & $59,548,000$ & $89,322,000$ & $3,220,000,000$ & $32,200,000$ & $64,400,000$ & $96,600,000$ \\
\hline Shirak & $400,500,000$ & $4,005,000$ & $8,010,000$ & $12,015,000$ & $576,900,000$ & $5,769,000$ & $11,538,000$ & $17,307,000$ \\
\hline Syunik & $629,400,000$ & $6,294,000$ & $12,588,000$ & $18,882,000$ & $830,500,000$ & $8,305,000$ & $16,610,000$ & $24,915,000$ \\
\hline Vayots Dzor & $700,500,000$ & $7,005,000$ & $14,010,000$ & $21,015,000$ & $588,000,000$ & $5,880,000$ & $11,760,000$ & $17,640,000$ \\
\hline Tavush & $1,090,500,000$ & $10,905,000$ & $21,810,000$ & $32,715,000$ & $1,506,200,000$ & $15,062,000$ & $30,124,000$ & $45,186,000$ \\
\hline
\end{tabular}

Source: The calculations were done by the author

Hotel tax rates in each community area had to be set by the council of that community within the above mentioned rates.

However, this law was not adopted. At first, it was wrong to define it as a local tax that enhances the financial capacity of the community and promotes tourism in the communities, as the hotel facilities are not equally distributed in the communities, so one community could raise more money and the other less. In addition, setting rates was left to the discretion of each community council.

Taking into account the available statistics, according to the hotels revenue index in different regions, the possible amount to be collected from tourism tax at the rate of $1-3 \%$ by regions and by city of Yerevan is calculated in this article. 
Of course, taking into account the concentration of hotels in Yerevan, the amount of tourist tax in Yerevan will be 337,722,000-1,013,166,000 AMD, in Kotayk - 32,200,00096,600,000 AMD, in Tavush - 15,062,000-45,186,000 AMD, and the least will be in Armavir - 417,000-1,251,000 AMD, in Ararat - 804,000-2,412,000 AMD.

So, as hotels are not equally distributed among communities, one region will raise more money and the other less. And by looking at the different communities in the regions, the imbalance of tax collected is more evident. All this proves that it is wrong to consider it as a local tax.

In this regard, the tourist tax proposed in this article may be more effective as it is not a local tax, but a state tax and collected funds will go towards tourism development throughout the country, and besides, the proposed rates will apply to the daily room rates and will depend on the number of bed/days (as in the case of many countries around the world). The money from tourism tax should be allocated to the Tourism State Committee, which, taking into account the sector's priorities set by its annual development plans, will provide appropriate funds for various events. However, a certain amount should be set as a minimum, which will be directed towards tourism development in specific regions and the rest to general events by the Committee.

Each region should have its own annual tourism development plan, and the above mentioned money should be spent on tourism product marketing, branding, infrastructure development in the regions, development of new tourism routes, etc.

\subsection{Survey results}

In order to find out the opinion of Armenians towards applying tourist tax, a survey was done during January-February 2020, in Yerevan and some regions among domestic tourists (in total, the number of respondents was 100 people. The respondents were selected in focus groups based on the number of their previous domestic travels in Armenia. As during 2020 the international arrivals were low because of Covid-19 restrictions and during some months it was a total lockdown, so only domestic tourists were included in the survey).

The respondents were asked some short questions which are presented below.

Table 6. The survey results about tourist tax

\begin{tabular}{|c|c|c|}
\hline \multicolumn{2}{|r|}{ Questions } & \multirow[t]{2}{*}{$\%$ of respondents } \\
\hline 1. & & \\
\hline$\checkmark$ & Up to 25 years old & 18 \\
\hline$\sqrt{ }$ & $26-35$ years old & 52 \\
\hline$\sqrt{ }$ & $36-50$ years old & 24 \\
\hline$\checkmark$ & 51 and older & 6 \\
\hline \multicolumn{3}{|c|}{ Gender } \\
\hline$\sqrt{ }$ & Male & 30 \\
\hline$\sqrt{ }$ & female & 70 \\
\hline \multicolumn{3}{|c|}{ 3. Level of monthly income } \\
\hline$\sqrt{ }$ & Up to $100.000 \mathrm{AMD}$ & 19 \\
\hline$\sqrt{ }$ & 100.001-200.000 AMD & 39 \\
\hline$\sqrt{ }$ & 200.001-300.000 AMD & 18 \\
\hline$\sqrt{ }$ & $300.001-400.000$ AMD & 18 \\
\hline$\sqrt{ }$ & 400.001 AMD and more & 6 \\
\hline \multicolumn{3}{|c|}{$\begin{array}{l}\text { 4. Do you think that applying tourist tax in } \\
\text { Armenian hotels ( } 1-3 \% \text { of daily rate) is a good step } \\
\text { for raising money for sphere development? }\end{array}$} \\
\hline$\sqrt{ }$ & Yes & 70 \\
\hline$\sqrt{ }$ & No & 27 \\
\hline
\end{tabular}




\begin{tabular}{lll}
\hline & I do not know & 3 \\
\hline 5. & Will you continue to stay at hotels if the tourist
\end{tabular}

5. Will you continue to stay at hotels if the tourist tax at rates $1-3 \%$ applies?

\begin{tabular}{|c|c|}
\hline $\begin{array}{l}\checkmark \text { Yes, sure I will continue like I do } \\
\text { today }\end{array}$ & 61 \\
\hline$\checkmark$ I will continue, but not as much as now & 21 \\
\hline$\checkmark \quad$ No, I will not stay at hotels any more & 3 \\
\hline$\checkmark \quad$ I do not know & 3 \\
\hline$\checkmark \quad$ Even now I do not stay at hotels & 12 \\
\hline $\begin{array}{l}\text { 6. In your opinion, what are the priorities to the } \\
\text { funding of which should be directed the allocated } \\
\text { money from this tax? }\end{array}$ & Respondents could mention more than one option \\
\hline $\begin{array}{l}\checkmark \text { marketing and advertisement (digital } \\
\text { marketing as well), }\end{array}$ & 35 \\
\hline$\checkmark$ investments in tourism infrastructures, & 50 \\
\hline $\begin{array}{l}\checkmark \text { construction of new tourism } \\
\text { attractions, }\end{array}$ & 10 \\
\hline $\begin{array}{l}\checkmark \text { other (adding tourism information } \\
\text { centers, informational signs in roads, } \\
\text { constructing public toilets, places for } \\
\text { storing luggage, doing investments in old } \\
\text { touristic places, etc.) }\end{array}$ & 20 \\
\hline 7. What other comments do you have? & $\begin{array}{l}\text { Mainly mentioned ideas are: } \\
\checkmark \text { The most important thing is to use the collected } \\
\text { money more effeciently, more targeted, } \\
\checkmark \text { To provide the compliance between the quality } \\
\text { and price of hotels, } \\
\checkmark \text { It will be good if } 25 \% \text { of the tax goes to state } \\
\text { budget, and the } 75 \% \text { - to the communities budget } \\
\text { where the tax was generated via tourism product, } \\
\checkmark \text { The tax is better to start from Yerevan and not } \\
\text { from newly developing tourism cities, } \\
\checkmark \text { Tourism specialists should do profound research } \\
\text { to define the priority projects and then collect money } \\
\text { for accomplishing them, } \\
\checkmark \text { It would be better to gather the tax money from } \\
\text { the hotels and not tourists. } \\
\checkmark \text { A new tax is not a good idea. }\end{array}$ \\
\hline
\end{tabular}

\section{Source: Based on the survey results}

The survey results show, that people mostly agree with the proposed tax (70\%). However, in some cases, just listening the word "tax", people were against its application, but when the purpose and significance were explained, they were ready to consider it as an option. They clearly stated that the problem is not that hotel prices may increase by $1-3 \%$, but the most important thing is to use the tax money more effeciently. Thus, the survey results show, that tourist tax may be a good source for raising money for tourism advancement.

Also, according to the respondents, it is important to do investments in tourism infrastructures, do marketing and advertising with the allocated money, etc.

Cross-tabulation analysis via SPSS shows the connection between the willingness of respondents to visit hotels and their response if they agree with the tax, or not. 
Table 7. Cross-tabulation between some factors

\begin{tabular}{|c|c|c|c|c|c|c|c|}
\hline \multicolumn{8}{|c|}{ agree $*$ visit crosstab } \\
\hline \multicolumn{8}{|c|}{ Count } \\
\hline & & \multicolumn{5}{|c|}{ visit } & \multirow[b]{2}{*}{ Total } \\
\hline & & $\begin{array}{c}\text { Yes, sure I } \\
\text { will continue } \\
\text { like I do } \\
\text { today }\end{array}$ & $\begin{array}{l}\text { Even now I } \\
\text { do not stay } \\
\text { at hotels }\end{array}$ & $\begin{array}{c}\text { I will } \\
\text { continue, but } \\
\text { not as much } \\
\text { as now }\end{array}$ & $\begin{array}{c}\text { No, I will } \\
\text { not stay at } \\
\text { hotels any } \\
\text { more }\end{array}$ & $\begin{array}{l}\text { I do } \\
\text { not } \\
\text { know }\end{array}$ & \\
\hline \multirow[t]{3}{*}{ agree } & Yes & 58 & 6 & 6 & 0 & 0 & 70 \\
\hline & No & 3 & 6 & 12 & 3 & 3 & 27 \\
\hline & $\begin{array}{l}\text { I do } \\
\text { not } \\
\text { know }\end{array}$ & 0 & 0 & 3 & 0 & 0 & 3 \\
\hline Tota & & 61 & 12 & 21 & 3 & 3 & 100 \\
\hline
\end{tabular}

Source: Based on the analysis of the survey results using SPSS software

The cross tabulation and Pearson Chi square testing shows that the significance level $\alpha$ is under 0.05 , the null hypothesis is rejected, and this means that in case of applying the tourist tax people will continue to stay at hotels.

Table 8. Chi-Square Testing

\begin{tabular}{lcc}
\hline & \multicolumn{2}{c}{ Pearson Chi-Square } \\
\cline { 2 - 3 } & Value & Sig. \\
\hline Do you think that applying tourist tax in Armenian hotels (1-3\% of & 59.079 & .000 \\
daily rate) is a good step for raising money for sphere development? & & \\
Will you continue to stay at hotels if the tourist tax at rates 1-3\% & & \\
applies?
\end{tabular}

Source: Based on the analysis of the survey results using SPSS software

It should be noted that in 2021 the amount of money provided for tourism will be 7,607,994.9 thousand AMD, 7,280,285.4 thousand AMD of which will be spent on improving infrastructure related to tourism in different regions of Armenia within the framework of the World Bank-supported "Local Economy and Infrastructure Development Program". $5,824,228.3$ thousand AMD from the above mentioned program will be from loans and 1,195,617.1 thousand AMD from co-financing (Law of the Republic of Armenia on the "State Budget 2021", 2020).

Table 9. Expenditures of the State Budget of the Republic of Armenia for 2020 -2021 according to the programs and measures implemented by the state bodies

\begin{tabular}{|c|c|c|c|}
\hline \multirow{2}{*}{ Index } & \multirow{2}{*}{$\begin{array}{l}\text { The names of the top budget executives, programs } \\
\text { and events }\end{array}$} & \multicolumn{2}{|c|}{ Amount, thousand AMD } \\
\hline & & 2020 & 2021 \\
\hline \multirow[t]{10}{*}{1190} & Program name & $6,303,893.0$ & $7,607,994.9$ \\
\hline & Tourism Development Program & & \\
\hline & The purpose of the program & & \\
\hline & $\begin{array}{l}\text { Increasing the competitiveness and recognition of } \\
\text { Armenia and Armenian tourism product }\end{array}$ & & \\
\hline & Description of the final result & & \\
\hline & Increase in the number of tourists & & \\
\hline & Program events & & \\
\hline & Event name & $125,684.0$ & $127,709.5$ \\
\hline & $\begin{array}{l}\text { Services of Planning, Implementation, } \\
\text { Coordination and Monitoring (Control) of State } \\
\text { Programs in Tourism Development }\end{array}$ & & \\
\hline & Event description & & \\
\hline
\end{tabular}




\begin{tabular}{|c|c|c|c|}
\hline & $\begin{array}{l}\text { Services of Policy Development and } \\
\text { Coordination: State Program Planning: } \\
\text { Implementation and Monitoring Services }\end{array}$ & & \\
\hline & Type of event & & \\
\hline & Service delivery & & \\
\hline \multirow[t]{6}{*}{11002} & Event name & $200,000.0$ & $200,000.0$ \\
\hline & Support to tourism development & & \\
\hline & Event description & & \\
\hline & $\begin{array}{l}\text { Implementation of measures aimed at increasing } \\
\text { Armenia's attractiveness for tourists }\end{array}$ & & \\
\hline & Type of event & & \\
\hline & Service delivery & & \\
\hline \multirow[t]{6}{*}{11004} & Event name & $55,451.3$ & $64,188.8$ \\
\hline & $\begin{array}{l}\text { Management of the World Bank-supported Local } \\
\text { Economy and Infrastructure Development } \\
\text { Program }\end{array}$ & & \\
\hline & Event description & & \\
\hline & $\begin{array}{l}\text { Local Economy and Infrastructure Development } \\
\text { Program with the purpose to improve tourism } \\
\text { infrastructure in different regions of Armenia }\end{array}$ & & \\
\hline & Type of event & & \\
\hline & Service delivery & & \\
\hline \multirow[t]{6}{*}{12001} & Event name & $5,922,757.7$ & $7,216,096.6$ \\
\hline & $\begin{array}{l}\text { Measures to improve tourism infrastructure in } \\
\text { different regions of Armenia in the framework of } \\
\text { World Bank-supported Local Economy and } \\
\text { Infrastructure Development Program }\end{array}$ & & \\
\hline & Event description & & \\
\hline & $\begin{array}{l}\text { Renovation of tourism-related infrastructures in } \\
\text { selected regions, including roads, parking lots, } \\
\text { water supply systems, lighting and new } \\
\text { construction }\end{array}$ & & \\
\hline & Type of event & & \\
\hline & Providing transfers & & \\
\hline
\end{tabular}

Source: Law of the Republic of Armenia on the "State Budget 2020", 2019,

Law of the Republic of Armenia on the "State Budget 2021", 2020

Table 10. Expenditures for 2021 credit programs and measures supported by foreign states and international organizations, thousand AMD

\begin{tabular}{|c|c|c|c|c|c|}
\hline \multicolumn{2}{|c|}{ Index } & \multirow{2}{*}{$\begin{array}{l}\text { The names of the top budget executives, } \\
\text { programs and events }\end{array}$} & \multirow{2}{*}{ Total } & \multicolumn{2}{|c|}{ including } \\
\hline Program & Measure & & & loans & Co-financing \\
\hline \multirow[t]{4}{*}{1190} & & Tourism Development Program & $7,280,285.4$ & $5,824,228.3$ & $1,456,057.1$ \\
\hline & & including & & & \\
\hline & 11004 & $\begin{array}{l}\text { Management of the World Bank-supported } \\
\text { Local Economy and Infrastructure } \\
\text { Development Program }\end{array}$ & $64,188.8$ & $51,351.0$ & $12,837.8$ \\
\hline & 12001 & $\begin{array}{l}\text { Measures to improve tourism infrastructure in } \\
\text { different regions of Armenia in the framework } \\
\text { of World Bank-supported Local Economy and } \\
\text { Infrastructure Development Program }\end{array}$ & $7,216,096.6$ & $5,772,877.3$ & $1,443,219.3$ \\
\hline
\end{tabular}

Source: Law of the Republic of Armenia on the "State Budget 2021", 2020

During 2019 in the framework of World Bank-supported Local Economy and Infrastructure Development Program, some tourist sites have been renovated: the Garni Stones Symphony, a part of the Kumayri district of Gyumri, the Tatev and Stepanavan roads, currently the surroundings of Khor Virap are being renovated. Dvin Archaeological Reserve, Goris 
Historic Streets and Old Goris Cave City will be among the improved tourist destinations in 2020 (From the first-hand: 2019 for tourism, 2019)

It is worth mentioning that in 2019 the spendings for World Bank-supported 'Local Economy and Infrastructure Development program', amounted to 1.791.740.200 AMD (Law of the Republic of Armenia on the "State Budget 2019", 2018).

\section{Discussion and conclusions}

Thus, the correlation and regression analysis in the paper shows that for developing tourism, increasing its contribution to GDP, it is important to do investments.

As a mean for doing investments, the paper explored international practice of applying tourism tax, which is directed to doing investments.

The research paper proposes to apply new tax in Armenia which will be applied in hotel facilities and will be paid by the tourists who stay at hotels. As already mentioned, the proposed tax rate is $1-3 \%$ of hotel prices per night. The tax is to be paid for maximum amount of 7 nights per guest. Also, guests under age 12 do not have to pay the tax.

The calculations are done in the article based on the data of hotel revenues and, based on it the possible amount of tax is defined. The main directions of spending the money should be tourism development areas: marketing, branding, investments in infrastructures, etc.

Also, the tax money should be directed to the Tourism Committee of the Republic of Armenia, which, taking into account the main priorities of the annual tourism development plan, will provide appropriate funds for various events. However, a certain amount is proposed to set as a minimum, which will be directed towards tourism development in specific regions and the rest to general events by the Committee.

Here are some suggestions for using the money gathered from tourism tax:

- Financing marketing activities (also digital marketing), which is very important for tourism promotion,

- Creating touristic brands for different regions,

- Improving tourism infrastructures, especially in the regions of the country,

- Financing the implementation of tourism programs in regions, etc.

The survey done during the research shows that people mainly agree with the idea of applying this tax, and they mention that the most important thing is to provide the effeciency of using the money.

\section{Limitations and recommendations for future study}

The limitation of the study is because of the lack of statistics on how many nights tourists spend in hotels and in what type of rooms they sleep depending on prices, it was not possible to calculate the amount of tourist tax more accurately. So, the only possible way was to calculate the tax with the proposed 1-3\% rate from the hotel revenues.

In future, the tourism statistics should be improved, which will show the occupations of hotels by the room types and prices, and based on it the tax money calculations may become more accurate.

Also, the number of survey respondents was only 100, and future study should include more people.

It is crutial to clearly present the necessity of this tax for tourism development, as from literature review and the survey results it becomes obvious, that when the main goals are presented clearly, the willingness of tourists to pay the tax is high. In this case, they feel more responsible for the promotion of the tourism sector in the RA. 


\section{References}

Armhotels online booking service, n.d. Retrieved from http://www.armhotels.am/EN/Hotels/Index

Christine, T. (2019). 41 countries around the world that charge a tourist tax, Insider. Retrieved from https://www.insider.com/countries-that-require-a-tourist-tax-2019-2

Central Bank of Armenia. (2021). Retrieved from https://www.cba.am/en/sitepages/exchangearchive.aspx

Dalir, S., Mahamadaminov, A., \& Olya, H. GT. (2020). Airbnb and taxation: Developing a seasonal tax system. Tourism Economics, 1-14. doi:10.1177/1354816620904894

Finance Liga, (2020). Since 2020, local taxes have risen. Which ones and how much, URL: https://finance.liga.net/ekonomika/novosti/v-2020-godu-vyrosli-mestnye-nalogi-kakiei-na-skolko

From the first-hand: 2019 for tourism. (2019). Banks.am. Retrieved from https://banks.am/am/news/interviews/18337?fbclid=IwAR05BNfwSZEjMgqNP5rCw1 Z9jR2xJtTL5PEvSTaRq8KTbTWNYNG0clcfaP0

Hudson, S., Meng, F., So, K. K. F., Smith, S., Li, J., \& Qi, R. (2019). The effect of lodging tax increases on US destinations, Tourism Economics, 1-15, doi:10.1177/1354816619890752

Interrailing packages, n.d., European tourist tax explained. Retrieved from https://www.interrailingpackages.com/european-tourist-tax-explained/

La Scala, A. E. (2013), Elementi ricostruttivi della "imposizione sul turismo": opportunità e limiti nel contesto del cd. Federalismo fiscal', in Ficari, V. \& Scanu, G. (edited by) "Tourism taxation": sostenibilità ambientale e turismo fra fiscalità locale e competitività, Giappichelli, Torino.

Law of the Republic of Armenia on the "State Budget 2019", (2018). Retrieved from https://www.arlis.am/DocumentView.aspx?docid=128646

Law of the Republic of Armenia on the "State Budget 2020", (2019). Appendix 1, Retrieved from https://www.arlis.am/

Law of the Republic of Armenia on the "State Budget 2021", (2020). Appendix 1, Retrieved from https://www.arlis.am/

Mak, J., (2015). Research note: Are hotel property taxes fully passed on to hotel guests? Implications from recent research on property tax incidence. Tourism Economics, 21(4), 899-905, doi:10.5367/te.2014.0378

Monitoring and travel, (2020). Love money, Tourist tax in Europe 2020: what you will pay in Spain, Italy and other hotspots. Retrieved from https://www.lovemoney.com/guides/52231/tourist-tax-in-europe-what-you-will-pay-inspain-italy-and-other-hotspots

Quarto, A. (2013). La politica fiscale nel settore turistico: un confronto internazionale. Rivista di Scienze del Turismo, 1-2, 27-52.

Responsible travel, n.d., Tourist taxes - what are they, and do they work?, Retrieved from https://www.responsibletravel.com/copy/tourist-taxes

Rinaldi, A. (2011). Le tasse sul turismo. Quali tipologie scegliere?. Rivista di Scienze del Turismo, 3, 97-104.

Rinaldi, A. (2014), Externalities and tourist tax. Evidence from Italy, Rivista di Scienze del Turismo-Ambiente Cultura Diritto Economia, 3(2), 79-91.

Rotaris, L., \& Carrozzo, M. (2019). Tourism taxes in Italy: A sustainable perspective. Journal of Global Business Insights, 4(2), 92-105. doi:10.5038/2640-6489.4.2.1079

Schubert, S. F. (2010), Coping with externalities in tourism: A dynamic optimal taxation approach., Tourism Economics, 16(2), 321-343. 
Sheng, L., Li, T., \& Wang, J. (2017). Tourism and externalities in an urban context: Theoretical model and empirical evidence. Cities, 70, 40-45.

Sheng, L., \& Tsui, Y. (2009). Taxing tourism: enhancing or reducing welfare?. Journal of Sustainable Tourism, 17(5), 627-635.

Tavares, K. (2011). Trends in Taxation on Tourism Services \& Products', University of Guelph, School of Hospitality and Tourism Management, Working Paper 6. Retrieved from http://atrium.lib.uoguelph.ca/xmlui/handle/10214/2578

TCdata 360, The World Bank, Capital Investment in Travel and Tourism, URL: https://tcdata360. worldbank.org/indicators/cap.inv.tat?country=BRA\&indicator=24674 \&viz=line_chart\&years $=1995,2028$

The Jakarta post, (2020), Amsterdam to raise its tourist tax this year, Retrieved from https://www.thejakartapost.com/travel/2020/01/09/amsterdam-to-raise-its-tourist-taxthis-year.html

Socio-economic situation of the RA in 2019 January-December, (2020), Statistical Committee of the RA, p. 139, URL: https://www.armstat.am/file/article/sv_12_19a_421.pdf

Socio-economic situation of the RA in January-May, (2019), p. 126. Retrieved from https://armstat.am/file/article/sv_05_19a_450.pdf

Socio-economic situation of the RA in January, (2019). p. 104, 106. Retrieved from https://www.armstat.am/file/article/sv_01_19a_421.pdf, https://www.armstat.am/file/article/sv_01_19a_422.pdf

Socio-economic situation of the RA in January-December. (2020). p. 143. Retrieved from https://www.armstat.am/file/article/sv_12_20a_421.pdf

The draft of the law on "Hotel tax" of the RA, (2009). developed by the Communities Finance Officers Association, article 6, 8

The regions of the Republic of Armenia and the city of Yerevan in numbers. (2019). 285-286, URL: https://www.armstat.am/file/article/marzer_2019_22.pdf

WTTC Travel \& Tourism Economic Impact Armenia. (2018). p. 1, URL: http://www.wttc.org

WTTC Travel \& Tourism Economic Impact Armenia. (2019). p. 1. Retrieved from https://www.wttc.org/economic-impact/country-analysis/country-data/

WTTC Travel \& Tourism Economic Impact Armenia. (2020). p. 1. Retrieved from http://www.wttc.org 